\title{
Adenosine Induced Apoptosis in BHK Cells via P1 Receptors and Equilibrative Nucleoside Transporters
}

\author{
Wentian Sun, Hoon Eng Khoo and Chee Hong Tan* \\ Department of Biochemistry, Faculty of Medicine, National University of Singapore, \\ 10 Kent Ridge Crescent, Singapore, 119260, Republic of Singapore
}

Received 6 October 2004, Accepted 3 December 2004

\begin{abstract}
Adenosine, as a ubiquitous metabolite, mediates many physiological functions via activation of plasma membrane receptors. Mechanisms of most of its physiological roles have been studied extensively, but research on adenosineinduced apoptosis (AIA) has only started recently. In this study we demonstrate that adenosine dose-dependently triggered apoptosis of cultured baby hamster kidney (BHK) cells. Adenosine-induced apoptotic cell death was characterized by DNA laddering, changes in nuclear chromatin morphology and phosphatidylserine staining. Apoptosis was also quantified by flow cytometry. Results suggest the involvement of adenosine $A_{1}$ and $A_{3}$ receptors as well as equilibrative nucleoside transporters in apoptosis induced by adenosine. These results indicate a receptor-transporter co-signaling mechanism in AIA in BHK cells. The involvement of $A_{1}$ and $A_{3}$ receptors also implies a possible apoptotic pathway mediated by $\mathbf{G}$ protein-coupled receptors.
\end{abstract}

Keywords: Adenosine, Adenosine receptor, Apoptosis, BHK cells, Nucleoside transporter

\section{Introduction}

Adenosine (Ado) is a primordial signaling molecule that modulates physiological responses in all mammalian tissues,

\footnotetext{
Abbreviations: Ado, adenosine; DIP, dipyridamole; DMPX, 3,7dimethyl-1-propargylxanthine; DPCPX, 1,3-dipropyl-8-cyclopentylxanthine; EHNA, erytro-9-(2-hydroxy-3-nonyl) adenine; MRS-1220, 9-chloro-2-(2-furyl)-5-phenylacetylamino-[1,2,4]-triazolo[1,5c]quinazoline; NBMPR/NBTI: nitrobenzylmercaptopurine ribonucleoside or S-(4-nitrobenzyl)-6-thioinosine.
}

*To whom correspondence should be addressed. Tel: 65-6874-3245; Fax: 65-6779-1453

Email: bchtanch@nus.edu.sg many of which have been well studied and documented (Abbracchio and Williams 2001a, Abbracchio and Williams 2001b). However, less attention has been paid to the study of adenosine-induced apoptosis (AIA) (Chow et al., 1997). While several researchers reported that adenosine or adenosine analogs have apoptotic effect on cells (Szondy 1994; Tanaka et al., 1994; Wakade et al., 1995; Szondy 1995; Abbracchio et al., 1995; Shneyvays et al., 1997; Ceruti et al., 1997; Kohno et al., 1998; Barbieri et al., 1998; Rounds et al., 1998; Peyot et al., 2000; Schrier et al., 2001; Di Iorio et al., 2002; Koshiba et al., 2002; Schrier et al., 2002), antiapoptotic effects of adenosine have also been reported (Walker et al.,1997; Yao et al., 1997). Both adenosine receptor-mediated pathways (Szondy 1994; Abbracchio et al., 1995; Shneyvays et al., 1997; Ceruti et al., 1997; Walker et al., 1997; Yao et al., 1997; Kohno et al., 1998; Barbieri et al., 1998; Peyot et al., 2000; Di Iorio et al., 2002) and transporter mediated pathways (Tanaka et al., 1994; Wakade et al., 1995; Szondy 1995; Rounds et al., 1998; Barbieri et al., 1998; Schrier et al., 2001; Di Iorio et al., 2002; Koshiba et al., 2002; Schrier et al., 2002) were suggested. The results appear to indicate that the mechanism(s) of adenosine-induced apoptosis may be more complicated than expected, involving multiple pathways through which adenosine induces apoptosis under various conditions and in different type of cells.

Four adenosine receptors, termed $\mathrm{A}_{1}, \mathrm{~A}_{2 \mathrm{~A}}, \mathrm{~A}_{2 \mathrm{~B}}$ and $\mathrm{A}_{3}$, have been cloned and characterized by pharmacological studies (Palmer et al., 1995). All of the four subtype adenosine receptors belong to the family of $\mathrm{G}$ protein-coupled receptors (GPCRs). $A_{2 A}$ and $A_{2 B}$ receptors couple with $G_{\alpha s}$, whereas $A_{1}$ and $A_{3}$ receptors mainly couple with $G_{\alpha i}$ and interact with phospholipase C (Ralevic et al., 1998) by which most of adenosine's physiological functions are mediated (Abbracchio and Williams 2001a, Abbracchio and Williams 2001b). In addition to being mediated by receptors, extracellular adenosine is also a substrate for the membrane nucleoside transporters, through which adenosine can enter cells and be sequentially phosphorylated intracellularly to AMP, ADP and 
ATP. This intracellular pathway is also responsible for some of adenosine's physiological functions (Cass et al., 1998). Membrane nucleoside transporters are categorized into two groups on the basis of transport mechanisms (Griffith et al., 1996). The equilibrative, or $\mathrm{Na}^{+}$-independent nucleoside transporters are "facilitators" and are driven solely by the concentration of nucleoside permeates. $\mathrm{Na}^{+}$-independent nucleoside transporters are further subdivided on the basis of sensitivity to NBMPR: es (equilibrative \& sensitive) type and ei (equilibrative \& insensitive) (Griffith et al., 1996). Concentrative nucleoside transporters are classified into 6 subtypes according to permeate selectivity and sensitivity to NBMPR: cif $(\mathrm{N} 1)$, cit $(\mathrm{N} 2)$, cib $(\mathrm{N} 3)$, cit $(\mathrm{N} 4)$, cs $(\mathrm{N} 5)$ and csg (N6) (Cass et al., 1998).

In this study, we found that adenosine played different roles in cell death at different adenosine concentrations. In BHK cells, very low concentrations $(2-5 \mu \mathrm{M})$ of adenosine enhanced cell proliferation slightly while higher concentrations (10$1000 \mu \mathrm{M})$ caused apoptosis, with medium concentrations (50$200 \mu \mathrm{M})$ showing decreased apoptotic effects. Using selective adenosine receptor antagonists, we were able to confirm that $A_{1}$ and $A_{3}$ Ado receptors mediated apoptosis induced by low concentrations $(20-50 \mu \mathrm{M})$ of adenosine; whereas both ei type nucleoside transporter and $\mathrm{A}_{1}$ and $\mathrm{A}_{3}$ Ado receptors mediated adenosine-induced apoptosis at high adenosine concentrations $(500-1000 \mu \mathrm{M})$. This study is the first to demonstrate that adenosine's physiological function can be co-mediated by both adenosine receptors and nucleoside transporters. In addition, this study provides evidence for the possible involvement of GPCRs in apoptosis, for which there is yet no firm conclusion.

\section{Materials and Methods}

Culture of BHK cells BHK cells were maintained in $\alpha$-MEM (Sigma M0894) supplemented with 10\% FBS, $20 \mathrm{mM} \mathrm{NaHCO}_{3}$, $5 \mathrm{mM}$ HEPES and $100 \mathrm{U} / \mathrm{ml}$ penicillin at $37^{\circ} \mathrm{C}$ in a humid atmosphere of $5 \% \mathrm{CO}_{2} /$ air. In this study, $24 \mathrm{~h}$ prior to any experiment, BHK cells were seeded on coverslips or in $75 \mathrm{~cm}^{2}$ culture flasks at the density of $1 \times 10^{4}$ cells $/ \mathrm{cm}^{2}$. When adenosine was present in medium, $1 \%$ heat inhibited $\mathrm{FBS}_{\mathrm{i}}\left(56^{\circ} \mathrm{C}, 2 \mathrm{~h}\right)$ was used instead of $10 \% \mathrm{FBS}, 5 \mu \mathrm{M}$ EHNA was added to medium.

Double-staining of BHK cells with annexin V-FITC and propidium iodide (PI) Externalization of phosphatidylserine and condensed/fragmented chromatin were detected by an annexin VFITC-Propidium Iodide double staining using an adaptation of the protocol outlined in the annexin V-FITC apoptosis detection kit (Pharmingen, BD Biosciences). Briefly, BHK cells seeded on coverslips in 6-well plates were incubated with $1 \mathrm{mM}$ adenosine for $2 \mathrm{~h}$ or $24 \mathrm{~h}$. At the end of incubation period, medium was replaced by fresh $\alpha$-MEM, annexin V-FITC and PI were added for an additional 30-minute incubation. Coverslips were then placed upside down on a glass slide and immediately observed by fluorescence microscopy (Carl Zeiss LSM 510).
Analysis of internucleosomal DNA fragmentation: DNA laddering BHK cells were seeded in 6 culture flasks. $24 \mathrm{~h}$ after medium in each flask was replaced with $\alpha$-MEM containing 0,10 , $20,500,1000 \mu \mathrm{M}$ adenosine or $10 \mu \mathrm{M}$ camptothecin, cells were incubated for another $24 \mathrm{~h}$. DNA fragmentation was determined using an adaptation of a described technique (Liu et al., 1996). Briefly, after shaking the flasks, weakly adherent and non-adherent cells were collected by centrifugation of the cell culture medium ( $200 \mathrm{~g}, 5 \mathrm{~min}$ ). Adherent cells were trypsinised, harvested and kept seperately. Cells were incubated at $37^{\circ} \mathrm{C}$ for $3 \mathrm{~h}$ in a lysis buffer consisting of, in $\mathrm{mM}$, Tris- $\mathrm{HCl}(\mathrm{pH} 8.0) 10$, EDTA 5, and $\mathrm{NaCl}$ 100 , as well as $0.5 \%$ SDS and $10 \mu \mathrm{g} / \mathrm{ml}$ proteinase $\mathrm{K}$ (Boehringer) under agitation. This incubation was followed by dropwise addition of $5 \mathrm{M} \mathrm{NaCl}$ to a final concentration of $1 \mathrm{M}$ and incubation at $4^{\circ} \mathrm{C}$ for $1 \mathrm{~h}$. After centrifugation at $15,000 \mathrm{~g}$ for $30 \mathrm{~min}$ at $4^{\circ} \mathrm{C}$, supernatants were recovered. DNA was extracted with an equal volume of $25: 24: 1$ phenol/chloroform/isoamyl alcohol (vol : vol : vol) and precipitated in the presence of an equal volume of isopropanol at $-20^{\circ} \mathrm{C}$ overnight. After centrifugation at $15,000 \mathrm{~g}$ for $10 \mathrm{~min}$ at $4^{\circ} \mathrm{C}$, the pellets were washed in $75 \%$ ethanol, resuspended in water and digested with $1 \mathrm{mg} / \mathrm{ml}$ DNase-free RNase for $30 \mathrm{~min}$ at $37^{\circ} \mathrm{C}$. DNA electrophoresis was carried out in $2 \%$ agarose gel containing $0.5 \mu \mathrm{g} / \mathrm{ml}$ ethidium bromide. DNA fragments were visualized under UV light.

Assessment of apoptosis by flow cytometry using DNA fragment measurements BHK cells seeded in 6-well plates were treated with receptor antagonists or transporter inhibitors in the absence or presence of various concentrations of adenosine for $24 \mathrm{~h}$. Cells in supernant were collected by centrifugation $(200 \mathrm{~g}, 5 \mathrm{~min})$ and combined with adherent cells which were trypsinised and harvested. Cells were then washed with $5 \mathrm{ml}$ PBS ( $\mathrm{pH}$ 7.2), fixed by dropwise addition of ice cold $70 \%$ ethanol for no less than $2 \mathrm{~h}$ and passed through $0.44 \mathrm{~mm}$ filter to remove aggregates. Prior to flow cytometry, cells were centrifuged at $200 \mathrm{~g}$ for $5 \mathrm{~min}$ to remove ethanol and stained with $1 \mathrm{ml} \mathrm{PI} /$ Triton X-100 staining solution with RNase A for $15 \mathrm{~min}$ at $37^{\circ} \mathrm{C}$. Apoptotic cells were quantified using flow cytometry (Becton Dickinson FACSVantage SE). Data were obtained from triplicates. 10,000 events were counted for each sample.

\section{Results and Discussion}

Induction of BHK cell apoptosis by adenosine Two hours after the induction of apoptosis with adenosine, BHK cells were double-stained with annexin V-FITC and PI. Phosphatidylserine was detected by annexin V-FITC (Fig. 1A) but no condensed or fragmented chromatin was detected by PI, indicating an early stage of apoptosis. Phosphatidylserine normally locates on the intracellular side of cell membrane in healthy cells. During the early stages of apoptosis, phosphatidylserine is known to flip over to the extracellular side of cell membranes. Thus exposed, it can be detected and visualized by annexin VFITC (Martin et al., 1995). The exposure of phosphatidylserine is regarded as a sign of early stage apoptosis (Homburg et al., 1995; Rimon et al., 1997). Induction of apoptosis by adenosine 
(A)

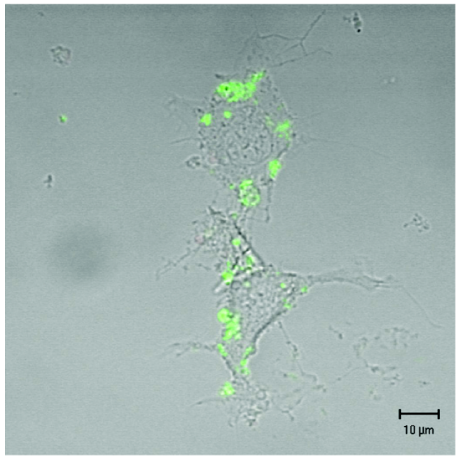

(B)

M12234567

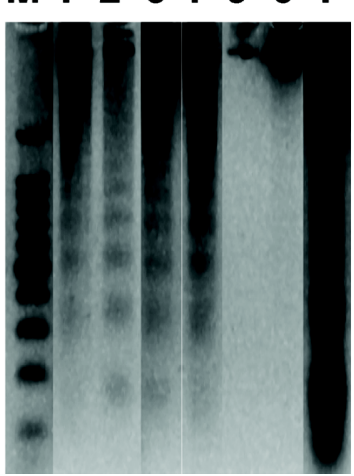

(C)

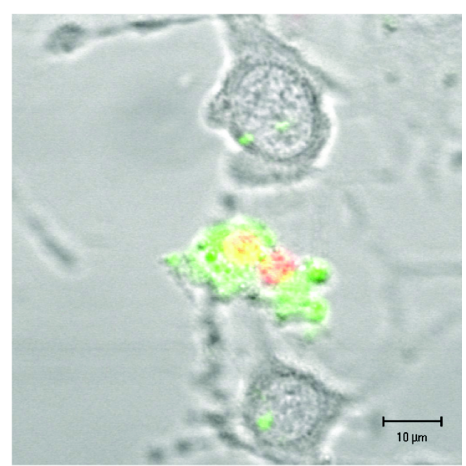

Fig. 1. Induction of BHK cell apoptosis by adenosine. (A) Photomicrograph showing the exposure of phosphatidylserine in adenosinetreated BHK cells. BHK cells were incubated in $\alpha$-MEM with $1 \mathrm{mM}$ adenosine for 2 hours, double-stained with annexin V-FITC and PI, examined by laser scanning microscope LSM 510 (Call Zeiss). Membrane phosphatidylserine was visualized by FITC, however no condensed or fragmented chromatin was detected, indicating an early stage of apoptosis. (B) Electrophoretic analysis of internucleosomal DNA fragmentation in adenosine-induced BHK cells. DNA was isolated from non-treated, adenosine-treated or camptothecin-treated BHK cells. M, 100-bp DNA ladder; lane 1-4, detached adenosine-treated BHK cells (lane1, $10 \mu \mathrm{M}$ Ado; lane 2, $20 \mu \mathrm{M}$ Ado; lane 3, $500 \mu \mathrm{M}$ Ado; lane 4, $1000 \mu \mathrm{M}$ Ado); lane 5, adherent adenosine-treated BHK cells $(1000 \mu \mathrm{M})$; lane 6, BHK cells without treatment, lane 7, camptothecin-treated $(10 \mu \mathrm{M})$ BHK cells. (C) Photomicrograph showing the nuclear morphology of adenosine-treated BHK cells. BHK cells were incubated $1 \mathrm{mM}$ adenosine for $24 \mathrm{~h}$, double-stained with annexin V-FITC and PI. Both morphology and condensed or fragmented chromatin suggest a late stage of apoptosis.

was confirmed by the presence of intranucleosomal DNA fragmentation of adenosine-treated BHK cells into multimers of $180 \mathrm{bp}$ nucleosomal units (Fig. 1B). In adherent adenosinetreated BHK cells and control cells, no DNA fragmentation was detected (lane 5, 6). A 24-hour exposure of BHK cells to $10,20,500$ or $1000 \mathrm{mM}$ adenosine resulted in DNA fragmentation typical of apoptosis (lane 1, 2, 3 and 4 respectively). Together with the morphological changes observed in BHK cells after a 24-hour exposure to $1 \mathrm{mM}$ adenosine (Fig. 1C), nucleus fragmentation with condensed chromatin detected by PI (Fig. 1C) suggests a late stage of apoptosis.

Dose-dependent BHK cell apoptosis induced by adenosine AIA in BHK cells, measured by detection of DNA fragmentation using flow cytometry, was shown to be strongly dependent on the extracellular adenosine concentration (Fig. 2 ). It should be noted that in the control cells without added adenosine, apoptosis remained at a low level ( $\sim 5 \%)$. Treatment with low concentrations of adenosine $(10-20 \mu \mathrm{M})$ decreased cell viability significantly to $60-70 \%$. Cell viability recovered with increasing concentrations of adenosine (50$200 \mu \mathrm{M})$ while higher concentrations $(500-1000 \mu \mathrm{M})$ resulted in reduced viability (Fig. 2). These results show a biphasic apoptotic effect of adenosine in BHK cells.

Involvement of adenosine receptors in adenosine-induced apoptosis in BHK cells AIA in BHK cells might occur in one of the following ways: (a) binding to one or more of its receptors, (b) intracellularly after adenosine uptake by

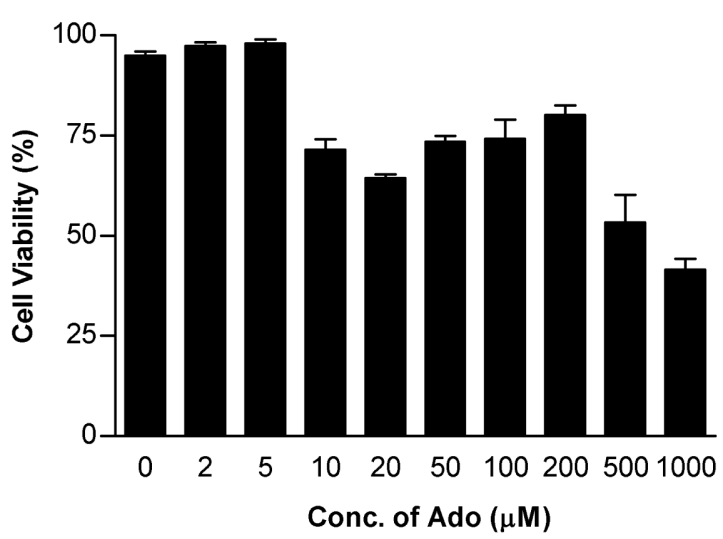

Fig. 2. Biphasic apoptotic effect of adenosine in BHK cells. BHK cells were treated with adenosine for $24 \mathrm{~h}$. Apoptotic cells (late stage) were counted by flow cytometer. Cell viability was calculated as the percentage of non-apoptotic cells. Data were obtained from triplicates, 10,000 events were counted for each sample.

nucleoside transporters or (c) a combination of both. To determine the possible adenosine receptor subtypes (if any) involved in AIA in BHK cells, all the four subtypes of adenosine receptors were investigated using selective receptor antagonists. The subtype specific adenosine receptor antagonists we used in this study were: DPCPX, an $\mathrm{A}_{1}$ receptor antagonist; DMPX, a non-specific $\mathrm{A}_{2}$ receptor antagonist and MRS 1220, an $\mathrm{A}_{3}$ receptor antagonist. As shown in Fig. 3A, DPCPX (7.5 and $30 \mu \mathrm{M})$ successfully blocked two thirds of the apoptosis induced by 20,500 and 

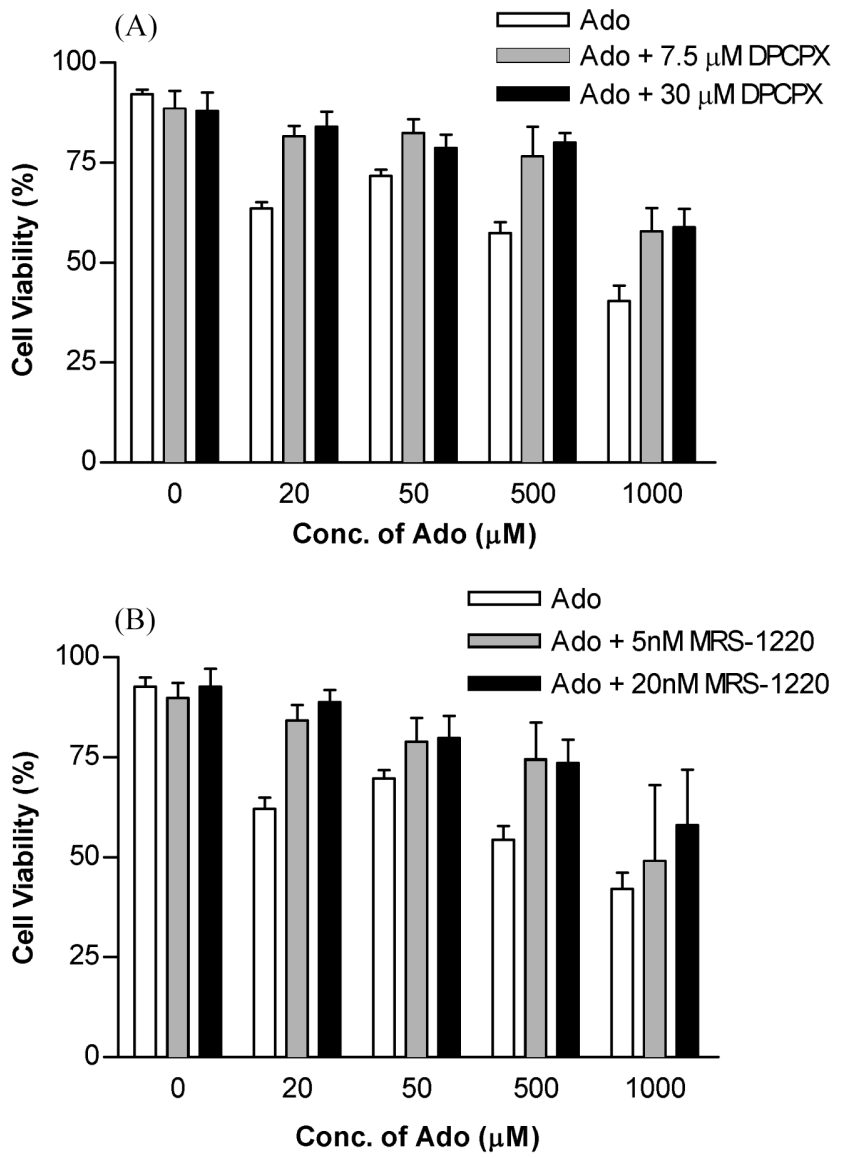

Fig. 3. (A) Effect of DPCPX on apoptosis induced by adenosine in BHK cells. BHK cells were treated with 20,50, 500 and $1000 \mu \mathrm{M}$ adenosine for $24 \mathrm{~h}$, in the absence or presence of 1 , 7.5 or $30 \mu \mathrm{M}$ DPCPX. Apoptotic cells (late stage) were counted by flow cytometer. Cell viability was calculated as the percentage of non-apoptotic cells. Data were obtained from triplicates, 10,000 events were counted for each sample. (B) Effect of MRS-1220 on apoptosis induced by adenosine in BHK cells. BHK cells were treated with $20,50,500$ and $1000 \mu \mathrm{M}$ adenosine for $24 \mathrm{~h}$, in the absence or presence of 1,5 or $20 \mathrm{nM}$ MRS-1220. Apoptotic cells (late stage) were counted by flow cytometer. Cell viability was calculated as the percentage of nonapoptotic cells. Data were obtained from triplicates, 10,000 events were counted for each sample.

$1000 \mu \mathrm{M}$ of adenosine. In contrast, the blocking of $\mathrm{A}_{2}$ receptors by DMPX had no significant effect on AIA (data not shown). Fig. $3 \mathrm{~B}$ shows that the $\mathrm{A}_{3}$ receptor specific antagonist, MRS-1220 (5 and $20 \mathrm{nM}$ ) could block one half to two thirds of the apoptosis induced by both low and high concentrations of adenosine. These results suggest that AIA in BHK cells may involve mediation via $A_{1}$ and $A_{3}$ adenosine receptors, unlike the report by Merighi et. al. (2002) who observed that $A_{2 A}$ and $A_{3}$ adenosine receptors appeared to be involved in the regulator of cell proliferation and survival in A375 cells. The expression of all four adenosine receptor subtypes $\left(A_{1}, A_{2 A}, A_{2 B}, A_{3}\right)$ in BHK cells was confirmed by immunochemistry (data not shown).
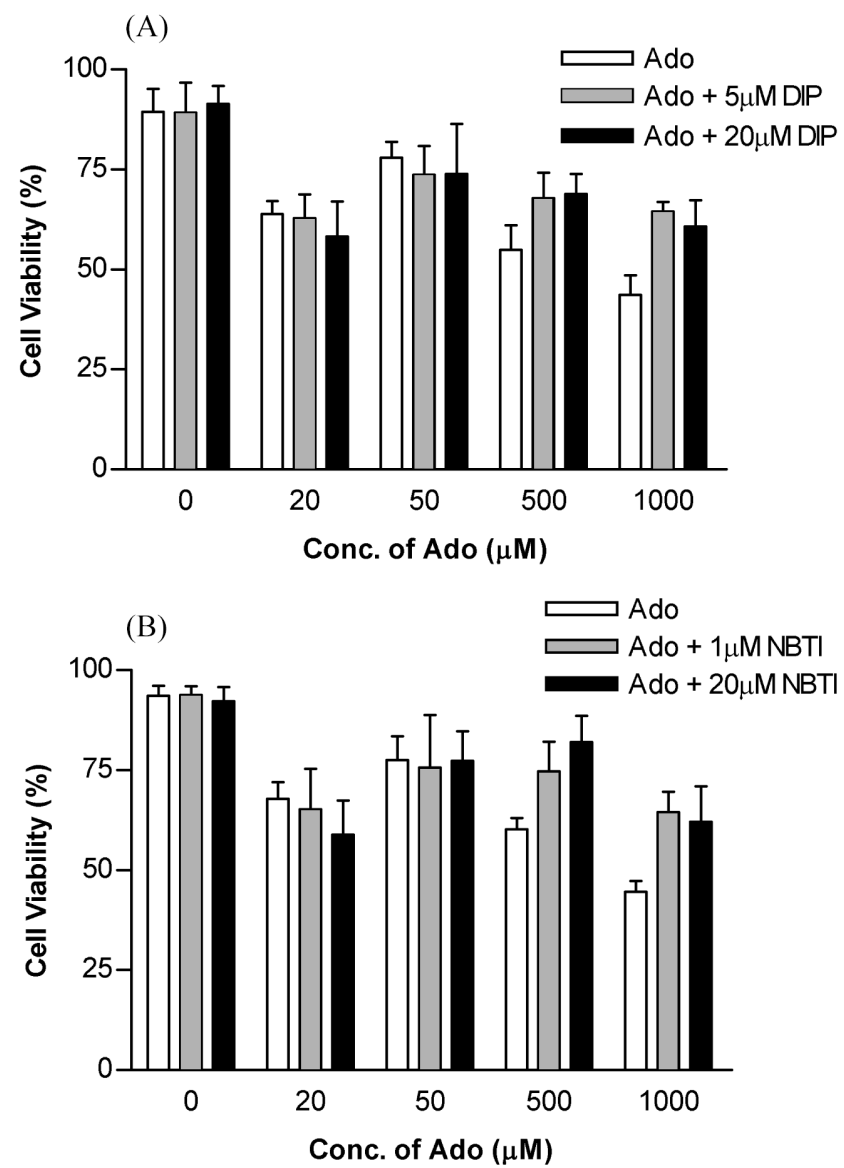

Fig. 4. (A) Effect of DIP on apoptosis induced by adenosine in BHK cells. BHK cells were treated with 20, 50, 500 and 1000 $\mu \mathrm{M}$ adenosine for $24 \mathrm{~h}$, in the absence or presence of 1,5 or 20 $\mu \mathrm{M}$ DIP. Apoptotic cells (late stage) were counted by flow cytometer. Cell viability was calculated as the percentage of nonapoptotic cells. Data were obtained from triplicates, 10,000 events were counted for each sample. (B) Effect of NBTI on apoptosis induced by adenosine in BHK cells. BHK cells were treated with $20,50,500$ and $1000 \mu \mathrm{M}$ adenosine for $24 \mathrm{~h}$, in the absence or presence of 1 , or $20 \mu \mathrm{M}$ NTBI. Apoptotic cells (late stage) were counted by flow cytometer. Cell viability was calculated as the percentage of non-apoptotic cells. Data were obtained from triplicates, 10,000 events were counted for each sample.

Involvement of nucleoside transporters in adenosineinduced apoptosis in BHK cells In addition to the receptormediated mechanism, nucleoside transporter-mediated pathways were also investigated in this study. Two transporter inhibitors were employed to identify the involvement of es and/or ei type equilibrative nucleoside transporters. Dipyridamole is an inhibitor which can block both es and ei type adenosine transport, whereas NBTI is only effective against es type. Fig. $4 \mathrm{~A}$ shows that dipyridamole could effectively protect $\mathrm{BHK}$ cells from apoptosis induced by high concentrations (500, $1000 \mu \mathrm{M})$ of adenosine but not by low concentrations $(20,50$ $\mu \mathrm{M})$. This suggests that in addition to the receptor-mediated pathway, nucleoside transporter-mediated pathway might also 
take part in AIA in BHK cells at high adenosine concentrations $(>500 \mu \mathrm{M})$. NBTI could not block this nucleoside transportermediated pathway as significantly as dipyridamole (Fig. 4B), implying the involvement of ei type nucleoside transporter. All these results suggest that the mechanism of AIA at low concentrations of adenosine may be $A_{1}$ and $A_{3}$ receptormediated; while the mechanism of AIA at high concentrations of adenosine may be co-mediated by ei type nucleoside transporter and $\mathrm{A}_{1}$ and $\mathrm{A}_{3}$ receptors. This hypothesis was further confirmed by the use of propentophylline which is both an adenosine transport inhibitor and a non-selective adenosine receptor antagonist (Parkinson et al., 1991; Parkinson et al., 1993) (data not shown). In our study only the involvement of equilibrative nucleoside transporters in AIA in BHK cells was shown, that of concentrative nucleoside transporters cit, cif and $c i b$ is still uncertain (subtype $c s$ and csg can be excluded as they are sensitive to NBTI).

Adenosine signaling mediated by receptors and uptake by nucleoside transporters has been extensively studied. The mechanisms of adenosine's physiological functions via receptors and nucleoside transporters are well documented. However, given the universal expression of adenosine receptors and nucleoside transporters in almost all mammalian cells, more complicated mechanisms can not be excluded. Our study provides a good reason to take into consideration the possibility of adenosine receptor-transporter co-signaling in the physiological micro-environment.

Membrane receptors are one of the most important functional cell membrane protein families. Currently cell surface receptors are classified into four classes: G proteincoupled receptors (GPCRs), ion-channel receptors, tyrosine kinase-linked receptors and receptor tyrosine kinases (RTKs) (Lodish et al., 2000). The latter two types of receptors have been shown to play an important role in apoptosis. However, even though the involvement of GPCRs in apoptosis has been implied by many scientists, it is still to be confirmed and a model of GPCR-mediated apoptosis is yet to be established. Our study as well suggests a high possibility for the existence of GPCR-mediated apoptotic pathway(s).

Acknowledgments This work was supported by a grant (R183-000-064-213) for biomedical research from the National Medical Research Council (NMRC) of Singapore. W.T. Sun is the recipient of an NUS (National University of Singapore) research scholarship.

\section{References}

Abbracchio, M. P., Ceruti, S., Barbieri, D., Franceschi, C., Malorni, W., Biondo, L., Burnstock, G. and Cattabeni, F. (1995) A novel action for adenosine: apoptosis of astroglial cells in rat brain primary cultures. Biochem. Biophys. Res. Commun. 213, 908-915.

Abbracchio, M. P. and Williams, M. (2001a) Purinergic and pyrimidinergic signalling $I$. Springer-Verlag, Berlin, Germany
Abbracchio, M.P., and Williams, M. (2001b) Purinergic and pyrimidinergic signalling II. Springer-Verlag, Berlin, Germany.

Barbieri, D., Abbracchio, M. P., Salvioli, S., Monti, D., Cossarizza, A., Ceruti, S., Brambilla, R., Cattabeni, F., Jacobson, K. A. and Franceschi, C. (1998) Apoptosis by 2chloro-2'-deoxy-adenosine and 2-chloro-adenosine in human peripheral blood mononuclear cells. Neurochem. Int. 32, 493504.

Cass, C. E., Young, J. D. and Baldwin, S. A. (1998) Recent advances in the molecular biology of nucleoside transporters of mammalian cells. Biochem. Cell Biol. 76, 761-770.

Ceruti, S., Barbieri, D., Veronese, E., Cattabeni, F., Cossarizza, A., Giammarioli, A. M., Malorni, W., Franceschi, C. and Abbracchio, M. P. (1997) Different pathways of apoptosis revealed by 2-chloro-adenosine and deoxy-D-ribose in mammalian astroglial cells. J. Neurosci. Res. 47, 372-383.

Chow, S. C., Kass, G. E. and Orrenius, S. (1997) Purines and their roles in apoptosis. Neuropharmacology 36, 1149-1156.

Di Iorio, P., Kleywegt, S., Ciccarelli, R., Traversa, U., Andrew, C. M., Crocker, C. E., Werstiuk, E. S. and Rathbon, M. P. (2002) Mechanisms of apoptosis induced by purine nucleosides in astrocytes. Glia 38, 179-190.

Griffith, D. A. and Jarvis, S. M. (1996) Nucleoside and nucleobase transport systems of mammalian cells. Biochim. Biophys. Acta 1286, 153-181.

Homburg, C. H., de Haas, M., von dem Borne, A. E., Verhoeven, A. J., Reutelingsperger, C. P. and Roos, D. (1995) Human neutrophils lose their surface $\mathrm{Fc}$ gamma RIII and acquire Annexin V binding sites during apoptosis in vitro. Blood 85, 532-540.

Kohno, Y., Sei, Y., Koshiba, M., Kim, H. O., Jacobson, K. A. and Shainberg, A. (1998) Induction of apoptosis in HL-60 human promyelocytic leukemia cells by adenosine A(3) receptor agonists. Exp. Cell Res. 243, 383-397.

Koshiba, M., Kosaka, H., Nakazawa, T., Hayashi, N., Saura, R., Kitamura, N. and Kumagai, S. (2002) 2-Chloroadenosine but not adenosine induces apoptosis in rheumatoid fibroblasts independently of cell surface adenosine receptor signaling. $\mathrm{Br}$. J. Pharmacol. 135, 1477-1486.

Liu, Y. and Kitsis, R. N. (1996) Induction of DNA synthesis and apoptosis in cardiac myocytes by E1A oncoprotein. J. Cell Biol. 133, 325-334.

Lodish, H., Berk, A., Zipursky, S. L., Matsudaira, P., Baltimore, D. and Darnell, J. E. (2000) Cell-to-cell signalling: hormones and receptors; in Molecular Cell Biology, Tenny, S. (ed.), pp. 852-854, W. H. Freeman and Co., New York, USA.

Martin, S. J., Reutelingsperger, C. P., McGahon, A. J., Rader, J. A., van Schie, R. C., LaFace, D. M. and Green, D. R. (1995) Early redistribution of plasma membrane phosphatidylserine is a general feature of apoptosis regardless of the initiating stimulus: inhibition by overexpression of $\mathrm{Bcl}-2$ and $\mathrm{Abl}$. $J$. Exp. Med. 182, 1545-1556.

Merighi, S., Mirandola, P., Milani, D., Varani, K., Gessi, S., Klotz, K. N., Leung, E., Baraldi, P. G. and Borea, P. A. (2002) Adenosine receptors as mediators of both cell proliferation and cell death of cultured human melanoma cells. J. Invest. Dermatol. 119, 923-933.

Palmer, T. M. and Stiles, G. L. (1995) Adenosine receptors. Neuropharmacology 34, 683-694.

Parkinson, F. E. and Fredholm, B. B. (1991) Effects of 
propentofylline on adenosine A1 and A2 receptors and nitrobenzylthioinosine-sensitive nucleoside transporters: quantitative autoradiographic analysis. Eur. J. Pharmacol. 202, 361-366.

Parkinson, F. E., Paterson, A. R., Young, J. D. and Cass, C. E. (1993) Inhibitory effects of propentofylline on [3H]adenosine influx. A study of three nucleoside transport systems. Biochem. Pharmacol. 46, 891-896.

Peyot, M. L., Gadeau, A. P., Dandre, F., Belloc, I., Dupuch, F. and Desgranges, C. (2000) Extracellular adenosine induces apoptosis of human arterial smooth muscle cells via $\mathrm{A}(2 \mathrm{~b})-$ purinoceptor. Circ. Res. 86, 76-85.

Ralevic, V. and Burnstock, G. (1998) Receptors for purines and pyrimidines. Pharmacol. Rev. 50, 413-492.

Rimon, G., Bazenet, C. E., Philpott, K. L. and Rubin, L. L. (1997) Increased surface phosphatidylserine is an early marker of neuronal apoptosis. J. Neurosci. Res. 48, 563-570.

Rounds, S., Yee, W. L., Dawicki, D. D., Harrington, E., Parks, N. and Cutaia, M. V. (1998) Mechanism of extracellular ATP- and adenosine-induced apoptosis of cultured pulmonary artery endothelial cells. Am. J. Physiol. 275, 379-388.

Schrier, S. M., van Tilburg, E. W., van der Meulen, H., Ijzerman, A. P., Mulder, G. J. and Nagelkerke, J. F. (2001) Extracellular adenosine-induced apoptosis in mouse neuroblastoma cells: studies on involvement of adenosine receptors and adenosine uptake. Biochem. Pharmacol. 61, 417-425.

Schrier, S. M., Florea, B. I., Mulder, G. J., Nagelkerke, J. F. and Ijzerman, A. P. (2002) Apoptosis induced by extracellular ATP in the mouse neuroblastoma cell line N1E-115: studies on involvement of $\mathrm{P} 2$ receptors and adenosine. Biochem. Pharmacol. 63, 1119-1126.

Shneyvays, V., Nawrath, H., Jacobson, K. A. and Shainberg, A. (1998) Induction of apoptosis in cardiac myocytes by an A3 adenosine receptor agonist. Exp. Cell Res. 243, 383-397.

Szondy, Z. (1994) Adenosine stimulates DNA fragmentation in human thymocytes by $\mathrm{Ca}^{2+}$-mediated mechanisms. Biochem. $J$. 304, 877-885.

Szondy, Z. (1995) The 2-chlorodeoxyadenosine-induced cell death signalling pathway in human thymocytes is different from that induced by 2-chloroadenosine. Biochem. J. 311, 585-588.

Tanaka, Y., Yoshihara, K., Tsuyuki, M. and Kamiya, T. (1994) Apoptosis induced by adenosine in human leukemia HL-60 cells. Exp. Cell Res. 213, 242-252.

Wakade, T. D., Palmer, K. C., McCauley, R., Przywara, D. A. and Wakade, A. R. (1995) Adenosine-induced apoptosis in chick embryonic sympathetic neurons: a new physiological role for adenosine. J. Physiol. 488, 123-138.

Walker, B. M., Rocchini, C., Boone, R. H., Ip, S. and Jacobson, M. A. (1997) Adenosine A2a receptor activation delays apoptosis in human neutrophils. J. Immunol. 158, 2926-2931.

Yao, Y., Sei, Y., Abbracchio, M. P., Jiang, J. L., Kim, Y. C. and Jacobson, K. A. (1997) Adenosine A3 receptor agonists protect HL-60 and U-937 cells from apoptosis induced by A3 antagonists, Biochem. Biophys. Res. Commun. 232, 317-322. 